\title{
Emergence stress and morphological constraints affect the species distribution and growth of subtropical intertidal seagrasses
}

\author{
Yoshiyuki Tanaka ${ }^{1, *}$, Masahiro Nakaoka $^{2}$ \\ ${ }^{1}$ Ocean Research Institute, University of Tokyo, Minamidai 1-15-1, Nakano, Tokyo 164-8639, Japan \\ ${ }^{2}$ Graduate School of Science and Technology, Chiba University, Yayoi-cho 1-33, Inage, Chiba 263-8522, Japan
}

\begin{abstract}
The effects of emergence stress and morphological constraints on the distribution and growth of 3 subtropical seagrass species, Cymodocea rotundata, C. serrulata and Thalassia hemprichii, were examined in a series of transplantation experiments and a laboratory desiccation experiment. C. rotundata and T. hemprichii occur in both the intertidal and subtidal zones off Ishigaki Island, southwest Japan, whereas C. serrulata is found only in the subtidal zone. Within the same species, intertidal shoots for both $C$. robundata and $T$. hemprichii are significantly smaller than subtidal shoots. A subtidal-to-intertidal transplantation experiment was conducted on 3 occasions: July and September 2001 and January 2002. In July and September, when the intertidal sites were exposed to air for a shorter period, shoot densities of the transplanted 3 species did not decrease. In contrast, the shoot densities of all 3 transplanted species decreased significantly in February, when the exposure to air was longer. The survival of $C$. serrulata ( $2 \%$ of the initial density) was much lower than that of $C$. rotundata (48\%) and T. hemprichii $(48 \%)$ ). In subtidal-to-intertidal transplants, the size of $C$. rotundata and $T$. hemprichii leaves decreased, approaching that of intertidal shoots, indicating high morphological plasticity. In situ observations revealed that transplanted seagrasses with large leaves were exposed to air for longer than were intertidal controls. In the desiccation experiment, $T$. hemprichii leaves had higher water contents than those of $C$. rotundata and C. serrulata. The morphological traits of $C$. rotundata and $T$. hemprichii and their ability to change shoot size appear to be related to the better survival of these species in the intertidal area as compared to C. serrulata. This is consistent with the observed variation in the species distribution in the intertidal zone.
\end{abstract}

KEY WORDS: Seagrass - Emergence - Desiccation - Morphological plasticity · Transplantation · Ishigaki Island

Resale or republication not permitted without written consent of the publisher

\section{INTRODUCTION}

In the intertidal zone, many benthic organisms have distinct patterns of vertical distribution, including macrophytes. It is generally believed that differences in desiccation tolerance are a major factor in determining the upper limits of species distribution (Norton 1986, Davison \& Pearson 1996, Abe et al. 2001). Specific zonation patterns with different upper limits have also been observed for tropical and temperate seagrasses (Mukai et al. 1987, Leuschner et al. 1998, Björk et al. 1999, De Troch et al. 2001, Seddon \& Cheshire
2001, Huong et al. 2003). Some studies have investigated the relationship between emergence stress and intertidal seagrass distribution. Leuschner et al. (1998) attributed the zonation patterns of Zostera noltii and $Z$. marina to the difference in their photosynthetic abilities at a low leaf water content. Seddon \& Cheshire (2001) showed that Amphibolis antarctica underwent desiccation more slowly than did Posidonia australis, which might be a reason for its greater abundance in the upper tidal level. Conversely, Björk et al. (1999) showed that tropical seagrass species that inhabit the uppermost part of the intertidal bed do not necessarily 
have the highest physiological desiccation tolerance. They suggested that morphological traits that minimize desiccation stress may be more important in determining species distribution. However, few field experiments have examined survival in response to emergence stress directly (e.g. Huong et al. 2003).

As with other plants, seagrasses show intraspecific morphological variation along environmental gradients. In deep habitats with low light availability, the leaves of Zostera marina, Posidonia oceanica, and Cymodocea nodosa become larger and thinner to capture light efficiently (Bintz \& Nixon 2001, Olesen et al. 2002). Ultraviolet radiation causes the leaves of $Z$. capricorni, Cymodocea serrulata, and Syringodium isoetifolium to become thicker to protect the UV-sensitive organelles (Abal et al. 1994, Dawson \& Dennison 1996). The leaves of Thalassia testudinum and $T$. hemprichii are shorter when exposed to fast currents (van Tussenbroek 1996, Tomascik et al. 1997), possibly to minimize water resistance and damage. However, little attention has been paid to the relationship between emergence stress and intraspecific morphological variation in seagrasses (Phillips 1967). Interspecies comparisons of morphological responses to emergence stress may help to explain the distributions of seagrass species in the intertidal and subtidal zones.

This study examined whether emergence stress influences the distributions of intertidal seagrass species and whether among- and within-species variation in morphological traits and plasticity is related to variation in species distribution. We focused on 3 dominant seagrasses in the tropical Indo-Pacific Ocean: Thalassia hemprichii, Cymodocea rotundata, and C. serrulata. Generally, T. hemprichii and C. rotundata are found higher on the intertidal gradient than is C. serrulata (Mukai et al. 1987, Björk et al. 1999, Y.T. \& H. Kayanne, pers. obs.). We conducted a transplantation experiment at a seagrass bed off Shiraho, Ishigaki Island, where the emergence stress varies greatly within a short distance owing to the steep depth gradient. Shoot survival, changes in leaf growth and length, and the emergence conditions of seagrass shoots were recorded. In addition, a desiccation experiment was conducted in the laboratory to examine the water loss rate of the leaves of the 3 species.

\section{MATERIALS AND METHODS}

Study site. This study was conducted at a seagrass bed off Shiraho, Ishigaki Island, in the Ryukyu Islands, southwest Japan $\left(24^{\circ} 20^{\prime} \mathrm{N}, 124^{\circ} 9^{\prime} \mathrm{E}\right.$, Fig. 1). The water level at this site is stable for several hours at low tide, because a well-developed coral reef crest separates the moat from the outer ocean (Kayanne et al. 1995).
The seagrass bed consists of numerous patches with a trapezoidal cross-section (Fig. 2). Patch area varies between 10 and $>100 \mathrm{~m}^{2}$. Usually, the tops of the patches emerge every day (intertidal), while the side surfaces of each patch never emerge (subtidal). Therefore, the duration of air exposure changes dramatically over very small spatial scales. The frequency and degree of emergence of the top surface level was estimated using a tide table (Japan Meteorological Agency 2000, 2001). Thalassia hemprichii and Cymodocea rotundata occur in both intertidal and subtidal areas, whereas C. serrulata occurs only in subtidal areas. The substrate conditions and other environmental factors in the intertidal and subtidal zones were similar.

In July 2001, 30 non-transplanted shoots of each species at each site (subtidal and intertidal) were tagged and punched using a hypodermic needle (total 150 shoots). The punched shoots for leaf growth measurement by the hole punch method (Dennison \& Alberte 1982) were collected 16 to $21 \mathrm{~d}$ later, and the morphological traits (leaf length, vertical rhizome length, sheath area and sheath dry weight) and leaf growth were measured. The length of the longest leaf of a shoot was used when making comparisons.

Transplantation experiment. A transplantation experiment was conducted to test whether the survival of the 3 seagrass species varied when they were transplanted from the subtidal to the intertidal zone, and whether transplantation caused any changes in mor-

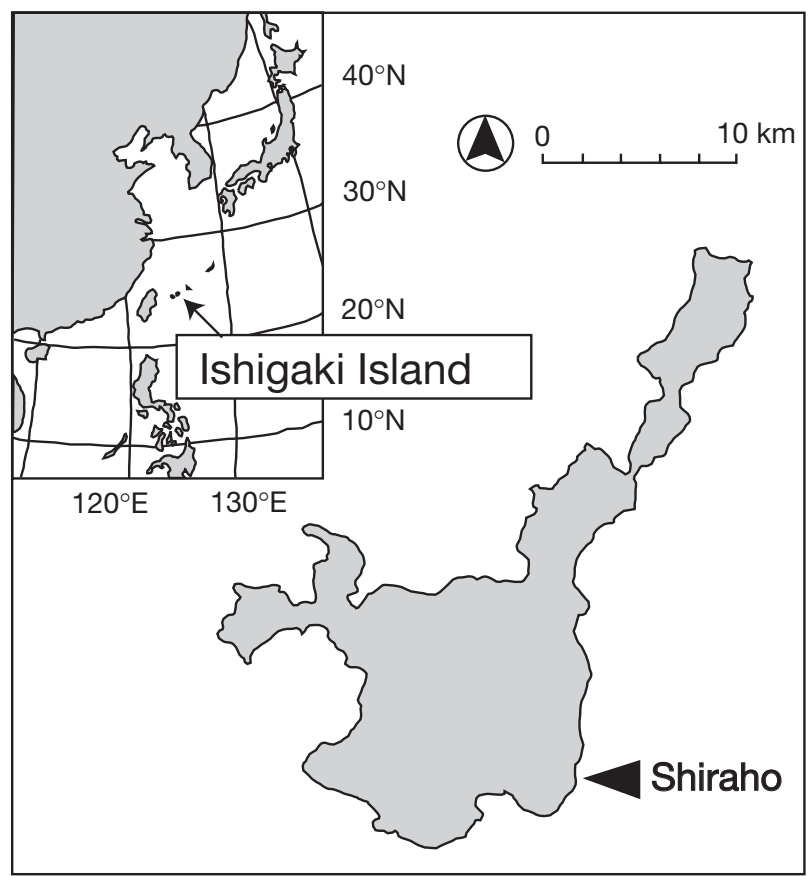

Fig. 1. Study site at Shiraho, Ishigaki Island, southwest Japan 

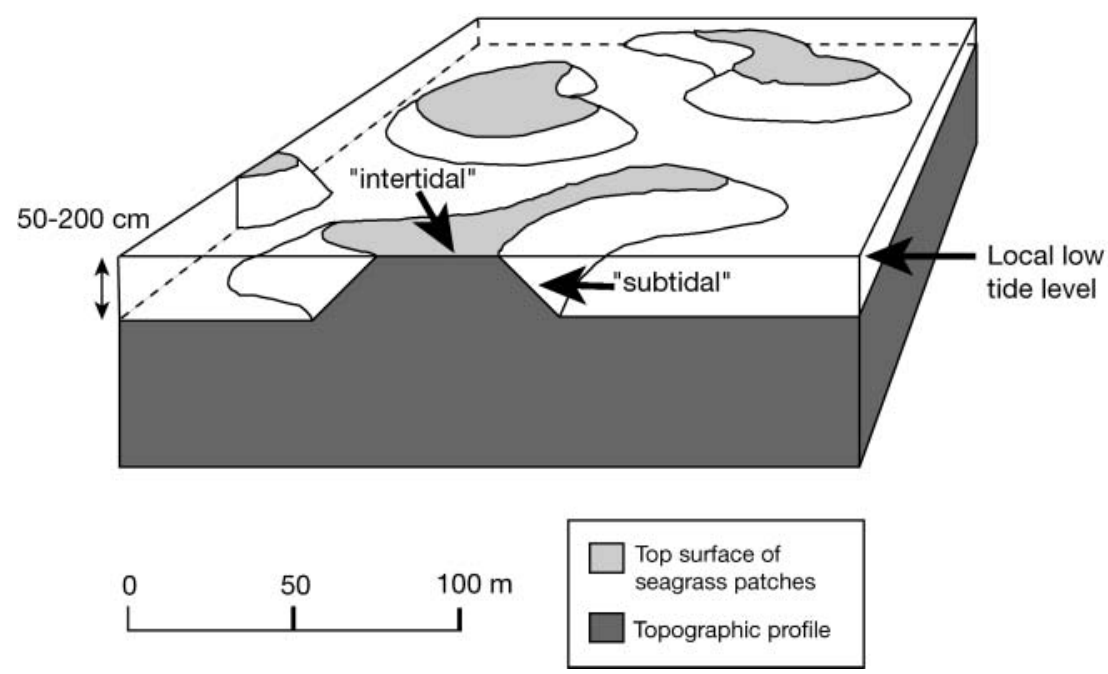

Fig. 2. Schematic presentation of the study site at Shiraho. Topographic profile of each seagrass patch was a trapezoid shape

dal-to-intertidal, subtidal-to-subtidal, and intertidal-to-intertidal) were compared for Thalassia hemprichii and Cymodocea rotundata, and 2 types (subtidal-to-intertidal and subtidal-tosubtidal) were compared for $C$. serrulata. In these comparisons, transplantation was a common factor. Simultaneously, non-manipulated shoots were compared with transplanted controls to check for any effect of the transplantation artifact in the first experiment, conducted in July.

Live shoot density was assessed approximately once a week after transplantation. For the plots transplanted in July, the growth rate was measured using the holepunch method (Dennison \& Alberte 1982). Five shoots per plot were tagged randomly and a hole was made using a hypodermic needle (total 200 shoots). The tagged shoots were collected 20 to 22 d later, and then leaf

phology. To account for seasonal changes in tidal regimes and other environmental factors, the experiment was repeated in 3 seasons: 2 July to 23 July 2001, 23 September to 18 October 2001, and 30 January to 25 February 2002. In addition to transplanting plants from the subtidal to the intertidal zone (the transplanted plots), the 3 species were transplanted within the subtidal zone to the same depth as they had been growing at previously (subtidal controls), as were the 2 species in the intertidal zone (intertidal controls). For each species and treatment, 5 replicate samples were prepared. The seagrass and associated sediment were removed using a stainless-steel corer (diameter $20 \mathrm{~cm}$, height $50 \mathrm{~cm}$ ). First, the corer was used to create a hole where the seagrass was to be transplanted. Then, using the same corer, a turf of seagrasses was dug up along with sediments to a depth of approximately $30 \mathrm{~cm}$ and moved gently to the prepared hole. The level of the sediment surface was carefully adjusted to that of the surrounding sediment. After transplantation, all seagrasses within $10 \mathrm{~cm}$ of each plot were removed and flags were set at each plot to facilitate identification of the plots. Most plots contained some untargeted species. The above and below ground parts of those species were carefully removed using scissors and by hand. The manipulation of the surrounding vegetation and untargeted species in the plots did not alter the light conditions of the targeted species because the canopies of the untargeted species were lower than those of the 3 species. Nevertheless, as possible spurious effects of transplantation, the growth rate and leaf length might have been reduced because the below sediment parts were damaged. To evaluate the actual effect of emergence, 3 types of transplantation (subti- growth and length were measured to the nearest $0.1 \mathrm{~mm}$ using calipers. The length of the longest leaf of a shoot was used when making comparisons. For the plots transplanted in September and January, the growth rate was measured by marking the leaves with plastic gem clips to follow temporal changes in the growth rate. Each gem clip was $25 \mathrm{~mm}$ long, $8 \mathrm{~mm}$ wide, and weighed $100 \mathrm{mg}$. The clips gripped the leaves but did not damage them. Two shoots per plot were marked with plastic gem clips (total 80 shoots per measurement). Each clip was attached to the basal part of the youngest leaf; if the youngest leaf was too small, the second youngest leaf was marked. Growth was measured repeatedly at 3 to $4 \mathrm{~d}$ intervals and the clips were reset after each measurement.

The plots that were transplanted in September and January were left in situ to examine long-term changes in morphological traits. The length of the longest leaf of a shoot and the position of the meristem (defined here as the vertical rhizome length plus the sheath length) were measured for 5 shoots randomly selected from a plot in February 2002 (147 d after transplantation for the September plots) and May 2002 (232 d after transplantation for the September plots, $103 \mathrm{~d}$ for the January plots).

Emergence conditions. During the spring tides in October and February, we observed the emergence conditions of the transplanted plots and intertidal controls within $10 \mathrm{~d}$ after transplantation. The emergence levels of each plot were recorded every hour for $7 \mathrm{~h}$, starting during the ebb tide when the water level was still higher than the mean sea level, through low tide, and finishing during the flood tide once all the plots were submerged again. For each treatment, 35 (5 plots 
Classification of emergence level

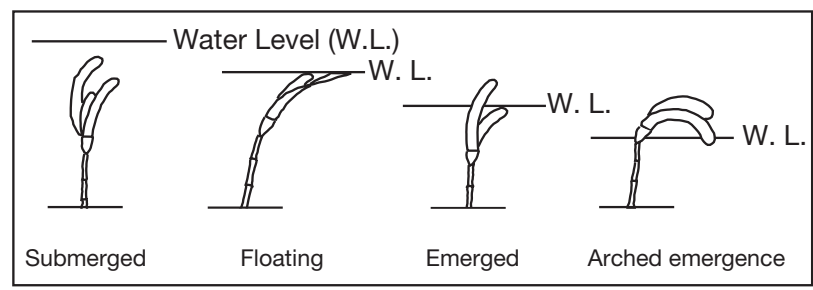

Fig. 3. Schematic presentation of emergence level classification for seagrass shoots. Each plot was categorized as one of the following 4 emergence levels: (1) submerged: no leaf reached water surface, (2) floating: at least 1 leaf reached water surface, (3) emerged: at least 1 leaf was emerged from the water, (4) arched emergence: more than half of the leaf blade was exposed to air

$\times 7)$ measurements of emergence levels were recorded as percentages. Using these data, the average emergence time of each plot was calculated for each treatment. Each plot was categorized into one of the following 4 emergence levels: submerged: no leaf reached the water surface; floating: at least 1 leaf reached the water surface; emerged: at least 1 leaf emerged above the water surface; and arched emergence: more than half of the leaf blade (in an arched position) was exposed to air (Fig. 3).

Desiccation experiment. Laboratory experiments were conducted in October 2001 and February 2002 to measure the water loss rate of seagrass leaves exposed to air while controlling both temperature and humidity $\left(27^{\circ} \mathrm{C}, 55 \%\right.$ in October and $24.5^{\circ} \mathrm{C}, 70 \%$ in February). Shoots of Cymodocea rotundata, C. serrulata and Thalassia hemprichii were collected with their belowground parts from the subtidal zone and kept in an outdoor container with circulating seawater for a few days. Just before beginning the experiment, the second youngest leaves on the shoots were cut off at the border between the leaf and the sheath. Six leaves per species were gently wiped with a kitchen towel, weighed (IW, initial weight), and laid on corrugated cardboard, which was obtained by stripping away one side of the flat surface of ordinary cardboard, to minimize contact between the substrate and the leaf surface. The change in the weight of the leaves $\left(\mathrm{W}_{t}\right.$, weight at time $t$ ) was measured over $65 \mathrm{~min}$ at $5 \mathrm{~min}$ intervals in October and over $150 \mathrm{~min}$ at $10 \mathrm{~min}$ intervals in February. After completing the measurements, the leaves were dried at $105^{\circ} \mathrm{C}$ for at least $24 \mathrm{~h}$ and weighed (DW, dry weight). The change in the relative water content was calculated as $\left(\mathrm{W}_{t}-D W\right) /(\mathrm{IW}-\mathrm{DW})$ (Björk et al. 1999). Exponential curves were fitted to each water loss trace, and the desiccation coefficient was estimated using the following formula:

$$
I_{t}=I_{0} \mathrm{e}^{-k t}
$$

where $I_{t}$ is the water content at time $t_{1} I_{0}$ is the water content at time 0 , and $k$ is the desiccation coefficient.

Statistical analyses. The differences in the morphological traits (leaf length, vertical rhizome length, and sheath area) and leaf growth of the non-manipulated shoots of subtidal and intertidal sites for each species were tested using the $t$-test. The Welch correction was made before subjecting data with heterogeneous variance to the $t$-test (checked using the F-test).

Temporal changes in the shoot density in the transplanted plots and controls were represented as the ratio of the density at each time step relative to the initial density. The variation in the relative shoot density among the 3 transplantation types (transplanted plots, subtidal controls and intertidal controls) of Thalassia hemprichii and Cymodocea rotundata, and between the transplanted plots and subtidal controls of C. serrulata was tested using repeated-measure ANOVA. The data on relative shoot density were arcsine-transformed before conducting ANOVAs. The variation in leaf growth in July, when the hole-punch method was adopted, was tested using 1-way ANOVA, whereas data from September and January, when growth was measured repeatedly at 3 to $4 \mathrm{~d}$ intervals, were tested using repeated-measure ANOVA. Variations in leaf lengths in the transplanted plots and controls were tested using 1-way ANOVA for the 3 seasons. Variations in the position of the meristem of leaves in the transplanted plots and controls were tested using 1way ANOVA for the 3 seasons. The desiccation coefficients of the 3 species were also compared using 1-way ANOVA. When ANOVA detected significant variation among transplantation types or species, post-hoc comparisons were carried out with Scheffé's $F$ method (at a significance level of $\alpha=0.05$ ). For the shoot density data, post-hoc comparisons were conducted only for the data recorded at the end of each experiment. Before these analyses, the heterogeneity of variance was tested using Cochran's $C$-test.

\section{RESULTS}

\section{Tidal condition}

The frequency and duration of emergence changed seasonally. The predicted emergence frequency was highest and the total emergence time was longest in January 2002 (Table 1). By contrast, these values were lowest and shortest in July 2001 and should have been intermediate in September 2001; however, low atmospheric pressure associated with several typhoons in September 2001 resulted in elevated sea levels and high waves. Consequently, the actual tide level in this period was higher than predicted by the tide table. 
Table 1. Emergence period and frequency at local low tide level in the intertidal part of the study site

\begin{tabular}{|lccccc|}
\hline & Period & Days & $\begin{array}{c}\text { Total } \\
\text { emergence } \\
\text { (h) }\end{array}$ & $\begin{array}{c}\text { Emergence } \\
\text { frequency } \\
\text { (no.) }\end{array}$ & $\begin{array}{c}\text { Average emergence time } \\
\text { /emergence } \\
\text { /day } \\
\text { (h) }\end{array}$ \\
\hline Jul (2001) & 2 Jul to 23 Jul & 21 & 83 & 19 & 4.4 \\
Sep (2001) & 23 Sep to 18 Oct & 25 & 145 & 37 & 4.0 \\
Jan (2002) & 30 Jan to 25 Feb & 26 & 215 & 43 & 5.9 \\
Year (2001 to 2002) & 1 Jun to 31 May & 365 & 2187 & 488 & 4.0 \\
\end{tabular}
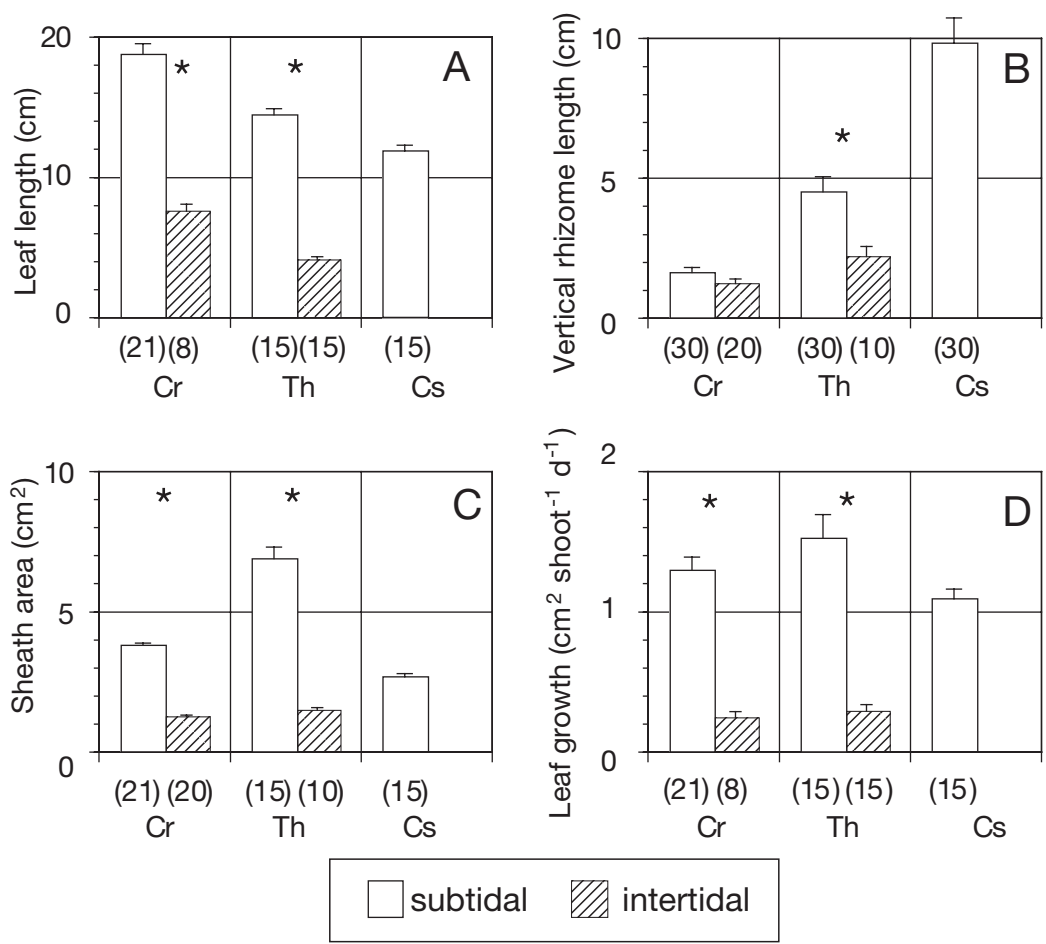

Fig. 4. Cymodocea rotundata $(\mathrm{Cr})$, Thalassia hemprichii $(\mathrm{Th})$ and C. serrulata (Cs). (A) Leaf length, (B) vertical rhizome length, (C) sheath area, and (D) leaf growth in natural conditions in July 2001 at sites with different emergence stress. Columns are means and error bars are SE of the mean. *: significant difference between the subtidal and the intertidal. The numbers in parentheses indicate sample sizes. C. serrulata was not observed in the intertidal

hemprichii). The sheath areas of $C$. rotundata and $T$. hemprichii were larger in the subtidal zone (Fig. 4C, $t$-test; $t=24.58, \mathrm{p}<0.001$ for C. rotundata and $t=12.86, \mathrm{p}<0.001$ for $T$. hemprichii). The leaf growth rates of $T$. hemprichii and C. rotundata were higher in the subtidal zone (Fig. 4D, $t$-test; $t=10.53, \mathrm{p}<0.001$ for $C$. rotundata and $t=7.11, \mathrm{p}<0.001$ for $T$. hemprichii). Sheath dry weight, which was measured only for the subtidal populations of each species, was largest for $T$. hemprichii (mean $\pm \mathrm{SE}$, $211.9 \pm 14.6 \mathrm{mg} \mathrm{DW} \mathrm{shoot}^{-1}$ ) followed by $C$. rotundata $(52.6 \pm 12.9)$ and $C$. serrulata $(32.8 \pm 5.9)$.

\section{Transplantation experiment}

Shoot density

The shoot density of Cymodocea rotundata increased in July in all of the treatments, whereas those of Thalassia hemprichii and C. serrulata did not (Fig. 5A). The among-treatment variation was not significant for the 3 species (Table 2A). In September, the shoot densities of the transplanted and

\section{Variation in seagrass morphology and growth with tide level}

Under natural conditions, the leaves of Cymodocea rotundata and Thalassia hemprichii were longer in the subtidal zone than in the intertidal zone (Fig. 4A, $t$-test; $t=12.3, \mathrm{p}<0.001$ for $C$. rotundata and $t=20.6, \mathrm{p}<$ 0.001 for $T$. hemprichii). The lengths of vertical rhizomes of $C$. rotundata were similar in the subtidal and intertidal zones, but those of $T$. hemprichii were longer in the subtidal zone (Fig. 4B, $t$-test; $t=1.60, \mathrm{p}=0.058$ for $C$. rotundata and $t=3.63, \mathrm{p}<0.001$ for $T$. intertidal controls of $C$. rotundata increased, as did that of transplanted C. serrulata during the last $10 \mathrm{~d}$ of the experimental period. The shoot density did not change in the other treatments (Fig. 5B). Significant amongtreatment variation was detected only in C. rotundata (Table 2B). The post-hoc comparison revealed that the intertidal controls had the greatest shoot density, followed by the transplanted plots, and then the subtidal controls.

In January, the shoot density of Cymodocea rotundata decreased in all of the plots (Fig. 5C). The amongtreatment variation was significant (Table $2 \mathrm{C}$ ), and the 
survival of the subtidal controls was higher than that of the intertidal controls and plants in the transplanted plots. The shoot density in the plots of transplanted $C$. rotundata decreased significantly to $48 \%$ of the initial density within 1 mo. The shoot density also decreased in all of the Thalassia hemprichii plots (Fig. 5C). Significant among-treatment variation was found (Table 2C). The variation was greater in the subtidal and intertidal controls than in the transplanted plots. The shoot den- sity in transplanted $T$. hemprichii plots decreased to $48 \%$ of initial values (Fig. $5 \mathrm{C}$ ). The shoot density of $C$. serrulata decreased in both treatments (Fig. 5C). Significant among-treatment variation was detected (Table 2C), with a greater decrease in density in the transplanted plots. The shoot density in the transplanted plots of C. serrulata decreased to $2 \%$ of the initial density, and all of the shoots died by 25 February in 4 out of 5 plots.

A: Transplanted in July 2001
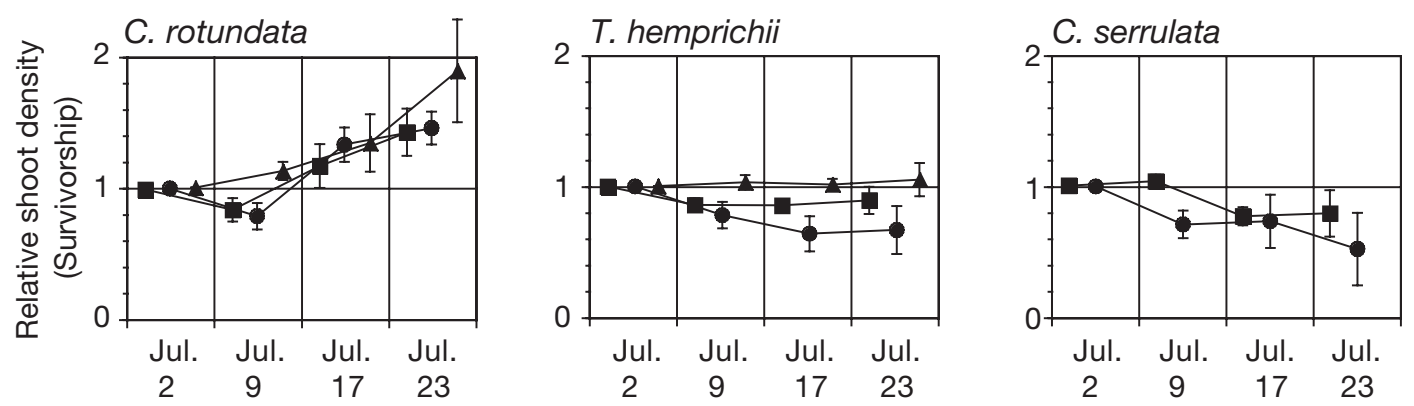

B: Transplanted in Sep. 2001
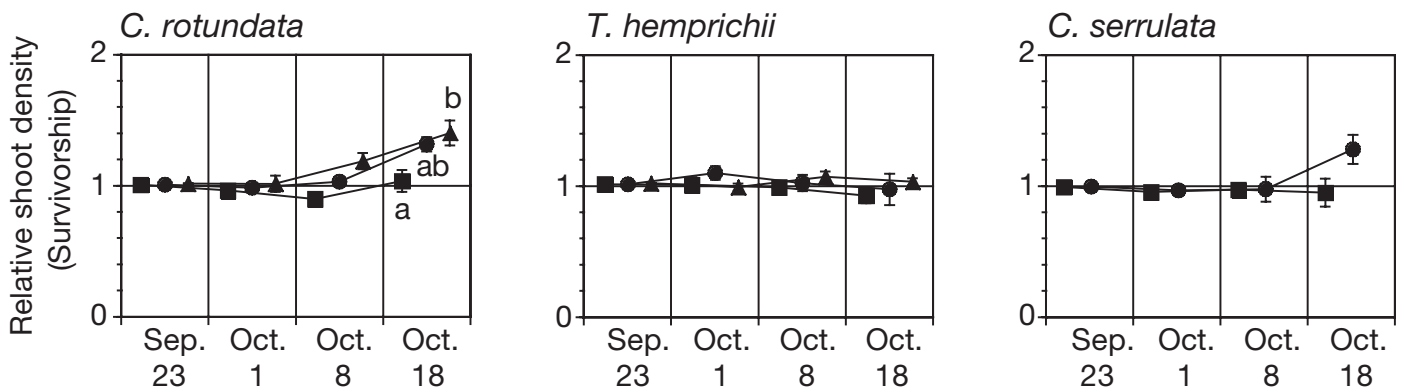

\section{C: Transplanted in Jan. 2002}
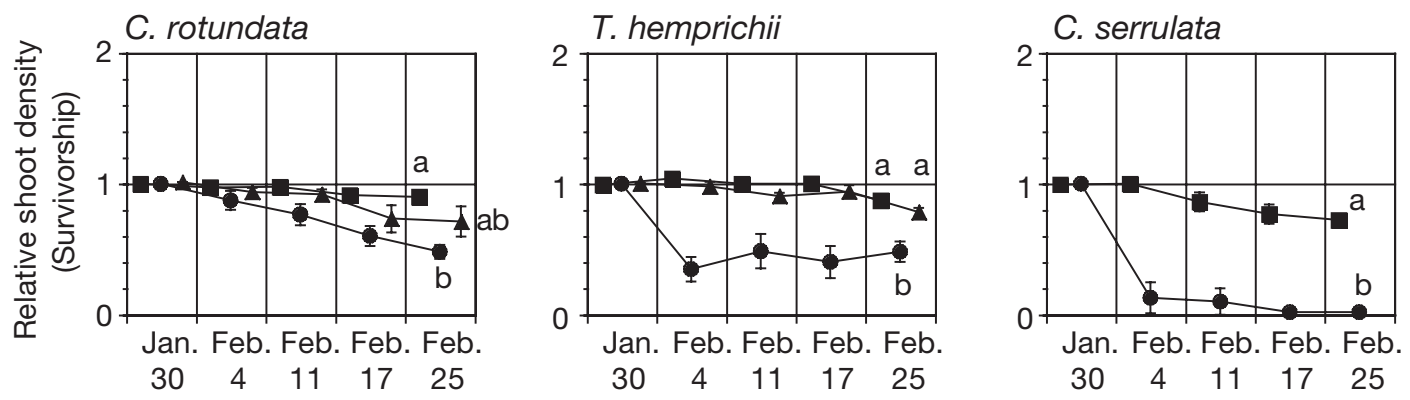

\section{- Subtidal controls $\rightarrow-$ Transplanted plots $\_$- Intertidal controls (Subtidal to Intertidal)}

Fig. 5. Cymodocea rotundata, Thalassia hemprichii and C. serrulata. Temporal changes in survivorship at transplantation experiments. $\square, \boldsymbol{\bullet} \mathbf{\Delta}$ are the means of 5 replicate plots, and error bars are the SE of the mean. Different letters denote pairs of treatments where significant variations were detected by the post-hoc comparisons 
Table 2. Cymodocea rotundata, Thalassia hemprichii and C. serrulata. Result of repeated-measure ANOVA to test the variation in shoot density among different transplantation treatments with temporal changes

\begin{tabular}{|c|c|c|c|c|c|}
\hline Species & Source of variance & df & MS & $F$ & $\mathrm{p}$ \\
\hline \multicolumn{6}{|c|}{ A. Transplanted in July 2001} \\
\hline \multirow[t]{7}{*}{ C. rotundata } & Between subjects & & & & \\
\hline & Treatments & 2 & 0.299 & 1.08 & 0.37 \\
\hline & Error & 12 & 0.277 & & \\
\hline & Within subjects & & & & \\
\hline & Temporal & 3 & 1.412 & 16.83 & $<0.001$ \\
\hline & Treatments $\times$ temporal & 6 & 0.080 & 0.95 & 0.47 \\
\hline & Error & 36 & 0.084 & & \\
\hline \multirow[t]{7}{*}{ T. hemprichii } & Between subjects & & & & \\
\hline & Treatments & 2 & 0.312 & 3.16 & 0.08 \\
\hline & Error & 12 & 0.099 & & \\
\hline & Within subjects & & & & \\
\hline & Temporal & 3 & 0.075 & 3.70 & 0.02 \\
\hline & Treatments $\times$ temporal & 6 & 0.042 & 2.05 & 0.08 \\
\hline & Error & 36 & 0.020 & & \\
\hline \multirow[t]{7}{*}{ C. serrulata } & Between subjects & & & & \\
\hline & Treatments & 1 & 0.237 & 1.30 & 0.29 \\
\hline & Error & 8 & 0.182 & & \\
\hline & Within subjects & & & & \\
\hline & Temporal & 3 & 0.224 & 2.87 & 0.06 \\
\hline & Treatments $\times$ temporal & 3 & 0.066 & 0.84 & 0.48 \\
\hline & Error & 24 & 0.078 & & \\
\hline \multicolumn{6}{|c|}{ B. Transplanted in September 2001} \\
\hline \multirow[t]{7}{*}{ C. rotundata } & Between subjects & & & & \\
\hline & Treatments & 2 & 0.148 & 8.83 & $<0.01$ \\
\hline & Error & 12 & 0.017 & & \\
\hline & Within subjects & & & & \\
\hline & Temporal & 3 & 0.221 & 19.81 & $<0.001$ \\
\hline & Treatments $\times$ temporal & 6 & 0.043 & 3.85 & $<0.01$ \\
\hline & Error & 36 & 0.011 & & \\
\hline \multirow[t]{7}{*}{ T. hemprichii } & Between subjects & & & & \\
\hline & Treatments & 2 & 0.011 & 0.41 & 0.67 \\
\hline & Error & 12 & 0.026 & & \\
\hline & Within subjects & & & & \\
\hline & Temporal & 3 & 0.009 & 0.99 & 0.41 \\
\hline & Treatments $\times$ temporal & 6 & 0.009 & 0.96 & 0.46 \\
\hline & Error & 36 & 0.009 & & \\
\hline \multirow[t]{7}{*}{ C. serrulata } & Between subjects & & & & \\
\hline & Treatments & 1 & 0.071 & 1.75 & 0.22 \\
\hline & Error & 8 & 0.041 & & \\
\hline & Within subjects & & & & \\
\hline & Temporal & 3 & 0.050 & 3.06 & 0.05 \\
\hline & Treatments $\times$ temporal & 3 & 0.065 & 3.97 & 0.02 \\
\hline & Error & 24 & 0.016 & & \\
\hline \multicolumn{6}{|c|}{ C. Transplanted in January 2002} \\
\hline \multirow[t]{7}{*}{ C. rotundata } & Between subjects & & & & \\
\hline & Treatments & 2 & 0.268 & 8.09 & $<0.01$ \\
\hline & Error & 12 & 0.033 & & \\
\hline & Within subjects & & & & \\
\hline & Temporal & 4 & 0.241 & 18.25 & $<0.001$ \\
\hline & Treatments $\times$ temporal & 8 & 0.035 & 2.68 & 0.02 \\
\hline & Error & 48 & 0.013 & & \\
\hline \multirow[t]{7}{*}{ T. hemprichii } & Between subjects & & & & \\
\hline & Treatments & 2 & 1.423 & 26.09 & $<0.001$ \\
\hline & Error & 12 & 0.055 & & \\
\hline & Within subjects & & & & \\
\hline & Temporal & 4 & 0.173 & 17.95 & $<0.001$ \\
\hline & Treatments $\times$ temporal & 8 & 0.112 & 11.61 & $<0.001$ \\
\hline & Error & 48 & 0.010 & & \\
\hline \multirow[t]{7}{*}{ C. serrulata } & Between subjects & & & & \\
\hline & Treatments & 1 & 4.816 & 85.96 & $<0.001$ \\
\hline & Error & 8 & 0.056 & & \\
\hline & Within subjects & & & & \\
\hline & Temporal & 4 & 0.652 & 62.90 & $<0.001$ \\
\hline & Treatments $\times$ temporal & 4 & 0.311 & 29.96 & $<0.001$ \\
\hline & Error & 32 & 0.010 & & \\
\hline
\end{tabular}

Leaf growth

In July, significant among-treatment variation was detected in the leaf growth of all 3 species (Fig. 6A, Table 3A). The leaves of Cymodocea rotundata and $C$. serrulata grew significantly less in the transplanted plots than in the subtidal controls, whereas the variation was marginally significant for Thalassia hemprichii (Scheffé's $F: \mathrm{p}=0.07$ ). The leaf growth of $C$. rotundata in transplanted plots was $42 \%$ of the subtidal controls, that of T. hemprichii was $55 \%$, and that of C. serrulata was $64 \%$. The leaf growth of $C$. rotundata did not differ significantly between the transplanted plots and intertidal controls, while that of the subtidal controls was greater than the former 2 treatments. The growth rate of $T$. hemprichii in the transplanted plots was intermediate between that of the subtidal and intertidal controls. The growth of the subtidal and intertidal controls did not differ significantly from that of the corresponding non-manipulated shoots of the 3 species, suggesting that any transplantation artifacts were negligible.

In September, the leaf growth of Thalassia hemprichii was significantly smaller in plants in the transplanted plots than in the subtidal control plots, but this was not the case for Cymodocea rotundata or C. serrulata; growth of $C$. rotundata and $T$. hemprichii was significantly higher in the transplanted plots than in the intertidal control plots (Fig. 6B, Table 3B).

In January, the leaf growth of all 3 species was less than half that in September. The growth in the transplanted plots was significantly lower than the subtidal controls and significantly higher than the intertidal controls for Cymodocea rotundata and Thalassia hemprichii (Fig. 6C, Table 3C). Although no statistical test was performed for $C$. serrulata because there were too few surviving shoots, the leaf growth of the transplanted plots was much slower than that of the subtidal controls (Fig. 6C). 
Leaf length

In July, the leaves in the transplanted plots were significantly shorter than those of the subtidal controls for all 3 species after $3 \mathrm{wk}$ (Table 4A). The leaf length in the transplanted plots was $64 \%$ that of the subtidal controls for Cymodocea rotundata, $71 \%$ for Thalassia hemprichii, and $80 \%$ for C. serrulata (Fig. 7A). The leaves of the transplanted $C$. rotundata were as short as those of the intertidal controls, whereas those of $T$. hemprichii were intermediate between the subtidal and intertidal controls. The leaf lengths of the subtidal and intertidal controls did not differ significantly from those of the corresponding non-manipulated shoots, except for subtidal T. hemprichii controls. In long-term observations of the September plots, leaves in the transplanted plots became significantly shorter than those in the subtidal controls, except for C. serrulata in May 2002, $232 \mathrm{~d}$ after transplantation (Fig. 7B, Table 4B). The leaf lengths of the transplanted plots of $C$. rotundata and $T$.

A: Transplanted in July 2001

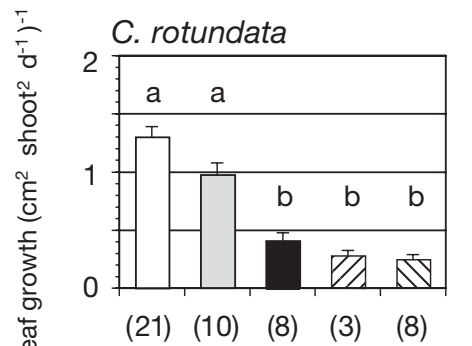

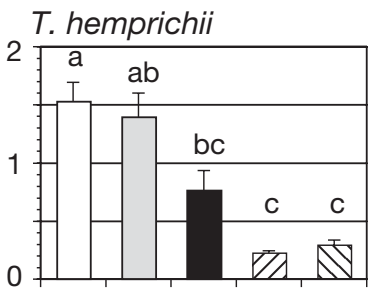

(15) (13) (9) (17) (15)

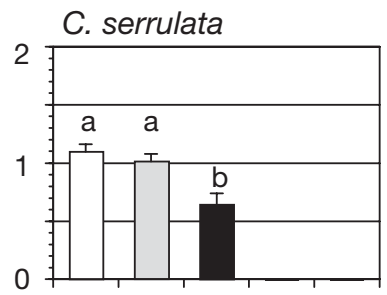

(15) (17) (10)

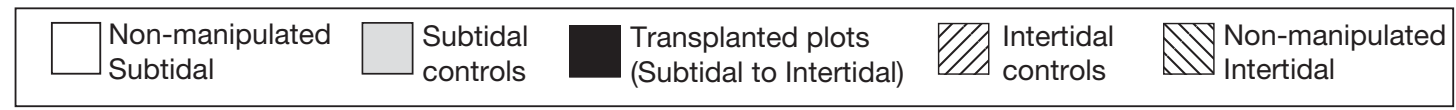

B: Transplanted in Sep. 2001
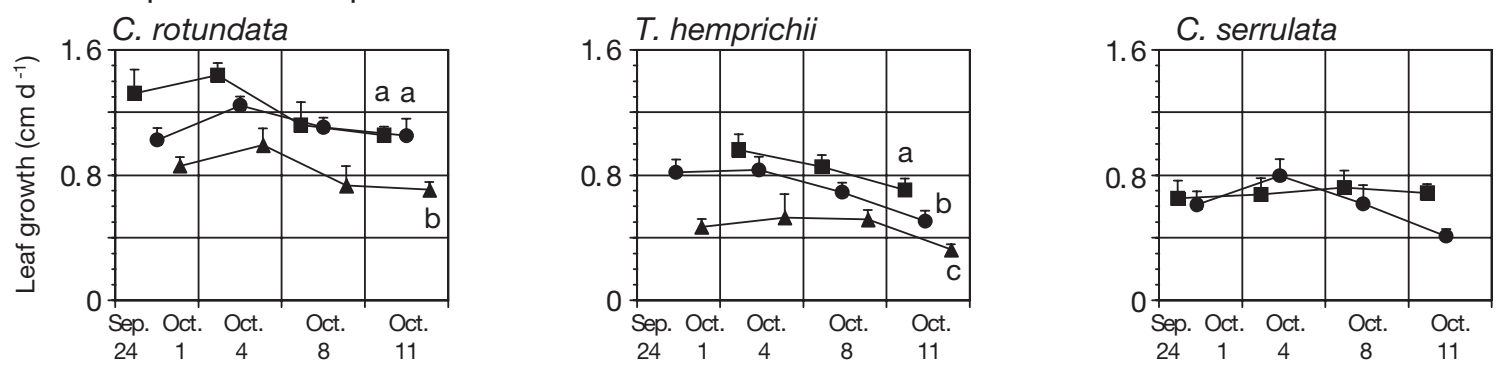

C: Transplanted in Jan. 2002

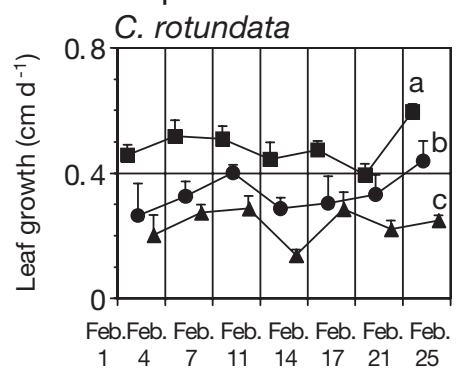

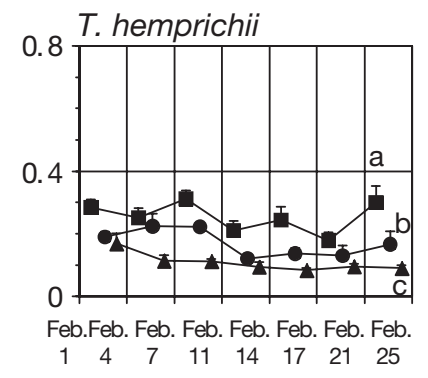

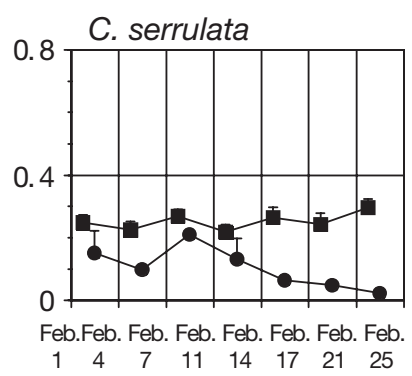

\begin{tabular}{|ll|}
\hline- Subtidal & - Transplanted plots \\
(Subtidal to Intertidal) & - -Intertidal controls \\
\hline
\end{tabular}

Fig. 6. Cymodocea rotundata, Thalassia hemprichii and C. serrulata. Difference in leaf growth among transplantation treatments. For July, columns are the means of replicates and error bars are the SE of the mean. The numbers in parentheses show the sample sizes. For September and January, $\mathbf{\square}, \boldsymbol{\bullet}, \mathbf{\Delta}$ are the means of replicates, and error bars are the SE of the mean. The sample size varied between 2 and 10. Different letters denote pairs of treatments where significant among-treatment variations were detected by the post-hoc comparisons 
hemprichii did not differ significantly from those of the intertidal control plots. In long-term observations of the January plots, the leaves in the transplanted plots were significantly shorter than those of the subtidal controls and were similar to those of the intertidal controls for $C$. rotundata and Thalassia hemprichii in May 2002, $103 \mathrm{~d}$ after transplantation (Fig. 7C, Table 4C). For C. serrulata, the long-term change in the transplanted plots was not examined because all the plots died by May 2002.

\section{Position of the meristem}

In long-term observations of the September plots, the position of the meristem of the transplanted plots became significantly shorter than the subtidal controls (Fig. 8A, Table 5A). The position of the meristem of the transplanted plots of Cymodocea rotundata and Thalassia hemprichii did not differ significantly from that of the intertidal control plots. In long-term observations of the January plots, the meristem in the transplanted plots was significantly shorter than that of the subtidal controls and was similar to the intertidal controls for $C$. rotundata and $T$. hemprichii in May 2002 (Fig. 8B, Table 5B). For C. serrulata, the longterm change in the transplanted plots was not examined because all the plants died by May 2002.

\section{Description of the emergence conditions}

In October, the intertidal controls of Cymodocea rotundata and Thalassia hemprichii never emerged, whereas the transplanted plots of all 3 species did emerge. A greater proportion of $C$. serrulata shoots was exposed to air for longer than was the case for either $C$. rotundata or T. hemprichii (Fig. 9). In February, all of the plots, including the intertidal $C$. rotundata and $T$. hemprichii controls, were subjected to prolonged exposure to air. Of the transplanted plots, T. hemprichii and C. serrulata experienced longer periods of exposure to air than did $C$. rotundata (Fig. 9).

\section{Desiccation experiments}

Cymodocea rotundata and C. serrulata showed similar patterns of water loss in the desiccation experiments, which were conducted in 2 seasons under different conditions $\left(27^{\circ} \mathrm{C}\right.$ and $55 \%$ humidity in October, $24.5^{\circ} \mathrm{C}$ and $70 \%$ humidity in February) (Fig. 10). The water content of Thalassia hemprichii leaves was sig-

Table 3. Cymodocea rotundata, Thalassia hemprichii and C. serrulata. Result of ANOVAs comparing leaf growth in different transplantation treatments. In July, non-manipulated shoots are added and 1-way ANOVA is used for testing leaf growth during the whole period. In September and February, repeated-measure ANOVA is used because growth was measured continuously basically in 3 to $4 \mathrm{~d}$ intervals. Analysis was not performed for C. serrulata in February 2002 because the number of survived shoots were too small for the statistical test

\begin{tabular}{|c|c|c|c|c|c|}
\hline Species & Source of variance & df & MS & $F$ & $\mathrm{p}$ \\
\hline \multicolumn{6}{|c|}{ A. Transplanted in July 2001} \\
\hline C. rotundata & $\begin{array}{l}\text { Treatments } \\
\text { Error }\end{array}$ & $\begin{array}{r}4 \\
45\end{array}$ & $\begin{array}{r}244.79 \\
10.70\end{array}$ & 22.87 & $<0.001$ \\
\hline T. hemprichii & $\begin{array}{l}\text { Treatments } \\
\text { Error }\end{array}$ & $\begin{array}{r}4 \\
64\end{array}$ & $\begin{array}{r}547.08 \\
23.59\end{array}$ & 23.19 & $<0.001$ \\
\hline C. serrulata & $\begin{array}{l}\text { Treatments } \\
\text { Error }\end{array}$ & $\begin{array}{r}2 \\
39\end{array}$ & $\begin{array}{r}66.05 \\
7.47\end{array}$ & 8.85 & $<0.001$ \\
\hline \multicolumn{6}{|c|}{ B. Transplanted in September 2001} \\
\hline \multirow{7}{*}{ C. rotundata } & Between subjects & & & & \\
\hline & Treatments & 2 & 1.024 & 16.35 & $<0.001$ \\
\hline & Error & 27 & 0.063 & & \\
\hline & Within subjects & & & & \\
\hline & Temporal & 3 & 0.277 & 6.00 & $<0.01$ \\
\hline & Treatments $\times$ temporal & 6 & 0.032 & 0.69 & 0.66 \\
\hline & Error & 33 & 0.046 & & \\
\hline \multirow[t]{7}{*}{ T. hemprichii } & Between subjects & & & & \\
\hline & Treatments & 2 & 0.793 & 17.85 & $<0.001$ \\
\hline & Error & 25 & 0.044 & & \\
\hline & Within subjects & & & & \\
\hline & Temporal & 2 & 0.354 & 21.63 & $<0.001$ \\
\hline & Treatments $\times$ temporal & 4 & 0.006 & 0.39 & 0.81 \\
\hline & Error & 20 & 0.016 & & \\
\hline \multirow[t]{7}{*}{ C. serrulata } & Between subjects & & & & \\
\hline & Treatments & 1 & 0.172 & 4.23 & 0.055 \\
\hline & Error & 18 & 0.041 & & \\
\hline & Within subjects & & & & \\
\hline & Temporal & 3 & 0.081 & 1.92 & 0.16 \\
\hline & Treatments $\times$ temporal & 3 & 0.082 & 1.96 & 0.15 \\
\hline & Error & 21 & 0.042 & & \\
\hline \multicolumn{6}{|c|}{ C. Transplanted in January 2002} \\
\hline \multirow[t]{7}{*}{ C. rotundata } & Between subjects & & & & \\
\hline & Treatments & 2 & 0.871 & 42.52 & $<0.001$ \\
\hline & Error & 27 & 0.020 & & \\
\hline & Within subjects & & & & \\
\hline & Temporal & 6 & 0.067 & 4.55 & $<0.001$ \\
\hline & Treatments $\times$ temporal & 12 & 0.013 & 0.85 & 0.60 \\
\hline & Error & 125 & 0.015 & & \\
\hline \multirow[t]{7}{*}{ T. hemprichii } & Between subjects & & & & \\
\hline & Treatments & 2 & 0.394 & 35.62 & $<0.001$ \\
\hline & Error & 27 & 0.011 & & \\
\hline & Within subjects & & & & \\
\hline & Temporal & 6 & 0.025 & 4.27 & $<0.001$ \\
\hline & Treatments $\times$ temporal & 12 & 0.007 & 1.20 & 0.29 \\
\hline & Error & 118 & 0.006 & & \\
\hline
\end{tabular}


Table 4. Cymodocea rotundata, Thalassia hemprichii and C. serrulata. Result of 1-way ANOVA comparing the leaf length among different transplantation treatments. Non-manipulated shoots are added for comparison in July

\begin{tabular}{|c|c|c|c|c|c|c|}
\hline Species & Date of observation & Source of variance & $\mathrm{df}$ & MS & $F$ & $\mathrm{p}$ \\
\hline \multicolumn{7}{|c|}{ A. Transplanted in July 2001} \\
\hline C. rotundata & Jul 2001 & $\begin{array}{c}\text { Treatments } \\
\text { Error }\end{array}$ & $\begin{array}{r}4 \\
45\end{array}$ & $\begin{array}{r}307.5 \\
8.9\end{array}$ & 34.4 & $<0.001$ \\
\hline T. hemprichii & Jul 2001 & $\begin{array}{c}\text { Treatments } \\
\text { Error }\end{array}$ & $\begin{array}{r}4 \\
64\end{array}$ & $\begin{array}{r}309.0 \\
3.2\end{array}$ & 97.4 & $<0.001$ \\
\hline C. serrulata & Jul 2001 & $\begin{array}{c}\text { Treatments } \\
\text { Error }\end{array}$ & $\begin{array}{r}2 \\
39\end{array}$ & $\begin{array}{r}24.0 \\
3.0\end{array}$ & 8.1 & $<0.01$ \\
\hline \multicolumn{7}{|c|}{ B. Transplanted in September 2001} \\
\hline \multirow[t]{2}{*}{ C. rotundata } & Feb 2002 & $\begin{array}{c}\text { Treatments } \\
\text { Error }\end{array}$ & $\begin{array}{r}2 \\
72\end{array}$ & $\begin{array}{r}69.1 \\
4.9\end{array}$ & 14.2 & $<0.001$ \\
\hline & May 2002 & $\begin{array}{c}\text { Treatments } \\
\text { Error }\end{array}$ & $\begin{array}{r}2 \\
72\end{array}$ & $\begin{array}{r}322.4 \\
5.0\end{array}$ & 64.2 & $<0.001$ \\
\hline \multirow[t]{2}{*}{ T. hemprichii } & Feb 2002 & $\begin{array}{c}\text { Treatments } \\
\text { Error }\end{array}$ & $\begin{array}{r}2 \\
72\end{array}$ & $\begin{array}{r}124.3 \\
4.2\end{array}$ & 29.6 & $<0.001$ \\
\hline & May 2002 & $\begin{array}{c}\text { Treatments } \\
\text { Error }\end{array}$ & $\begin{array}{r}2 \\
68\end{array}$ & $\begin{array}{r}167.5 \\
7.3\end{array}$ & 23.0 & $<0.001$ \\
\hline \multirow[t]{2}{*}{ C. serrulata } & Feb 2002 & $\begin{array}{c}\text { Treatments } \\
\text { Error }\end{array}$ & $\begin{array}{r}1 \\
38\end{array}$ & $\begin{array}{r}114.4 \\
4.5\end{array}$ & 25.2 & $<0.001$ \\
\hline & May 2002 & $\begin{array}{c}\text { Treatments } \\
\text { Error }\end{array}$ & $\begin{array}{r}1 \\
35\end{array}$ & $\begin{array}{l}4.1 \\
2.2\end{array}$ & 1.9 & 0.18 \\
\hline \multicolumn{7}{|c|}{ C. Transplanted in January 2002} \\
\hline C. rotundata & May 2002 & $\begin{array}{c}\text { Treatments } \\
\text { Error }\end{array}$ & $\begin{array}{r}2 \\
72\end{array}$ & $\begin{array}{r}546.5 \\
7.1\end{array}$ & 76.7 & $<0.001$ \\
\hline T. hemprichii & May 2002 & $\begin{array}{c}\text { Treatments } \\
\text { Error }\end{array}$ & $\begin{array}{r}2 \\
48\end{array}$ & $\begin{array}{r}353.5 \\
5.6\end{array}$ & 63.0 & $<0.001$ \\
\hline
\end{tabular}

Table 5. Cymodocea rotundata, Thalassia hemprichii and C. serrulata. Result of 1-way ANOVA comparing the position of meristem in different transplantation treatments

\begin{tabular}{|c|c|c|c|c|c|c|}
\hline Species & Date of observation & Source of variance & df & MS & $F$ & $\mathrm{p}$ \\
\hline \multicolumn{7}{|c|}{ A. Transplanted in September 2001} \\
\hline \multirow[t]{4}{*}{ C. rotundata } & Feb 2002 & Treatments & 2 & 9.62 & 5.25 & $<0.01$ \\
\hline & & Error & 72 & 1.83 & & \\
\hline & May 2002 & Treatments & 2 & 50.25 & 30.58 & $<0.001$ \\
\hline & & Error & 72 & 1.64 & & \\
\hline \multirow[t]{4}{*}{ T. hemprichii } & Feb 2002 & Treatments & 2 & 52.72 & 17.33 & $<0.001$ \\
\hline & & Error & 72 & 3.04 & & \\
\hline & May 2002 & Treatments & 2 & 54.19 & 82.65 & $<0.001$ \\
\hline & & Error & 68 & 0.66 & & \\
\hline \multirow[t]{4}{*}{ C. serrulata } & Feb 2002 & Treatments & 1 & 218.65 & 121.32 & $<0.001$ \\
\hline & & Error & 38 & 1.80 & & \\
\hline & May 2002 & Treatments & 1 & 79.60 & 19.51 & $<0.001$ \\
\hline & & Error & 35 & 4.08 & & \\
\hline \multicolumn{7}{|c|}{ B. Transplanted in January 2002} \\
\hline \multirow[t]{2}{*}{ C. rotundata } & May 2002 & Treatments & 2 & 103.92 & 146.92 & $<0.001$ \\
\hline & & Error & 72 & 0.71 & & \\
\hline \multirow[t]{2}{*}{ T. hemprichii } & May 2002 & Treatments & 2 & 97.03 & 59.68 & $<0.001$ \\
\hline & & Error & 48 & 1.63 & & \\
\hline
\end{tabular}


nificantly higher than those of C. rotundata and C. Serrulata. The desiccation coefficient of $T$. hemprichii leaves $(0.026)$ was lower than those of $C$. rotundata (0.046) and $C$. serrulata (0.049) in October (1-way ANOVA, $\left.F_{2,15}=48.36, \mathrm{p}<0.001\right)$, and that of $T$. hemprichii (0.013) was lower than those of $C$. rotundata (0.020) and C. serrulata (0.021) in February (oneway ANOVA, $\left.F_{2,15}=56.8, \mathrm{p}<0.001\right)$. In October, $T$. hemprichii leaves lost $80 \%$ of their water in $60 \mathrm{~min}$ and those of Cymodocea species did so in $30 \mathrm{~min}$. In Febru- ary, it took $120 \mathrm{~min}$ for T. hemprichii leaves and $60 \mathrm{~min}$ for C. rotundata and C. serrulata leaves to lose $80 \%$ of their water content (Fig. 10).

\section{DISCUSSION}

We found that the 3 dominant tropical seagrass species had different tolerances to emergence stress, which is thought to be the major factor influencing the

\section{Short-term observations}

\section{A: Transplanted in July 2001}

\section{C. rotundata}

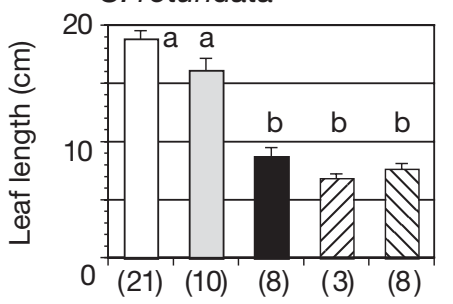

\section{T. hemprichii}

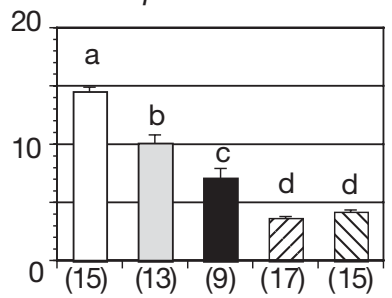

\section{C. serrulata}

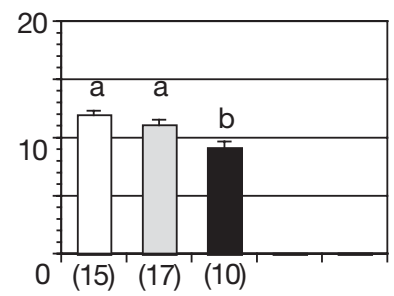

\section{Long-term observations}

B: Transplanted in Sep. 2001 C. rotundata

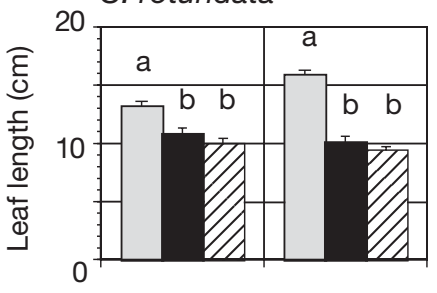

Feb. 2002 May 2002

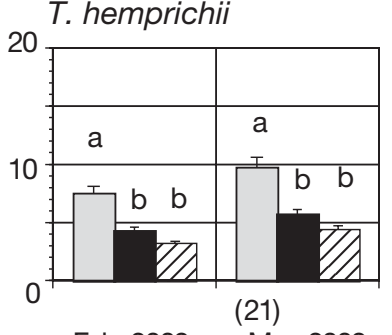

Feb. 2002 May 2002

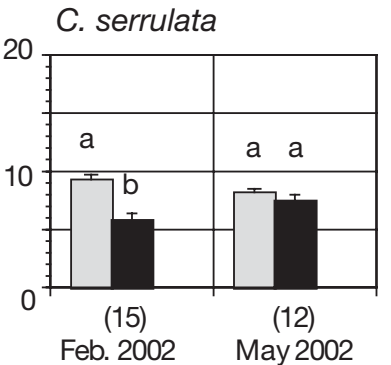

C: Transplanted in Jan. 2002
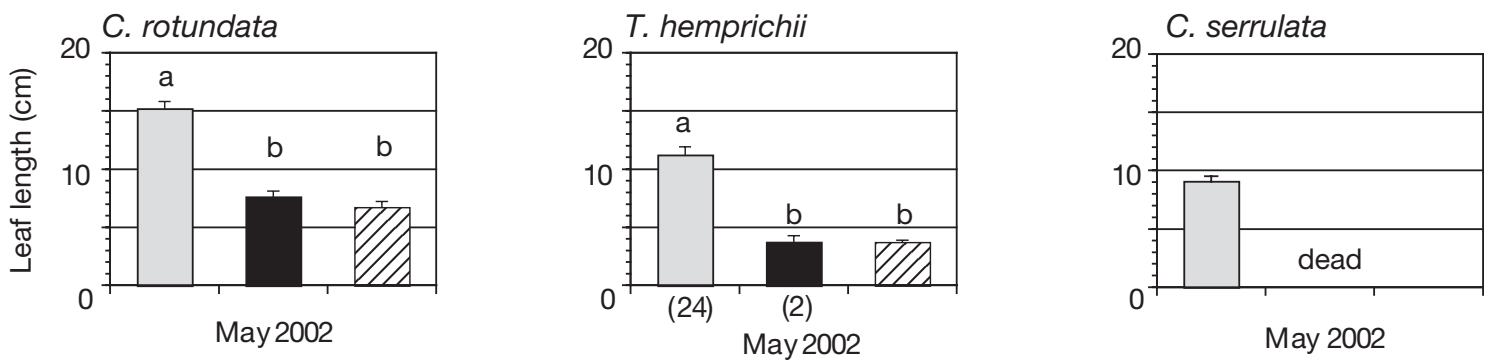

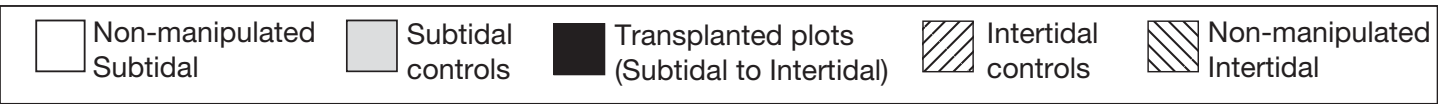

Fig. 7. Cymodocea rotundata, Thalassia hemprichii and C. serrulata. Temporal changes in leaf length in transplantation experiments. Columns are the means of replicates, and error bars are the SE of the mean. Different letters denote pairs of treatments where significant among-treatment variation was detected by the post-hoc comparison. Sample size was 25 for each treatment except those shown in parentheses 
upper limit of distribution of these species in the intertidal zone. Experimentally, we showed that Cymodocea serrulata is the most sensitive to emergence stress (Fig. 5); this result agrees with the distribution at
Shiraho, Ishigaki Island, where C. serrulata was not found in the intertidal zone. This also agrees with its intertidal distribution at other sites around Ishigaki Island (Tanaka 2004), in Papua New Guinea (Mukai et

A: Transplanted in July 2001
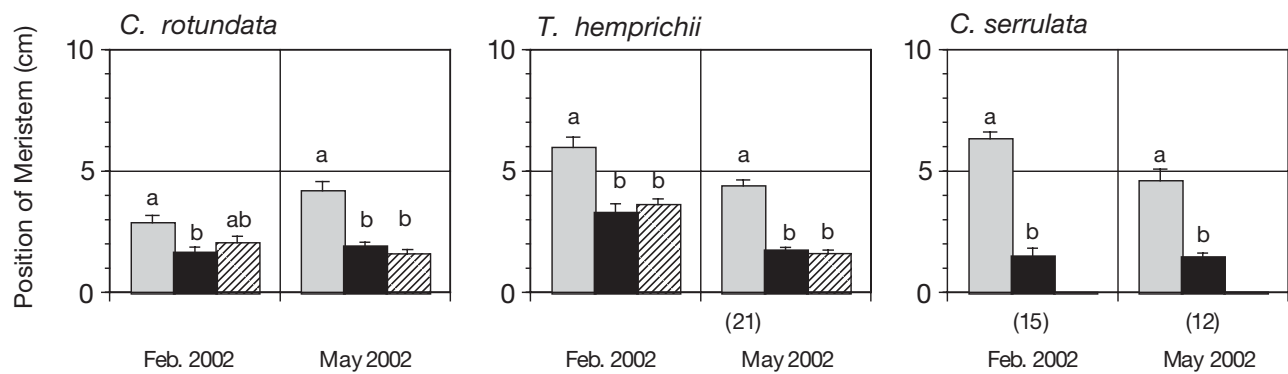

B: Transplanted in Jan. 2002
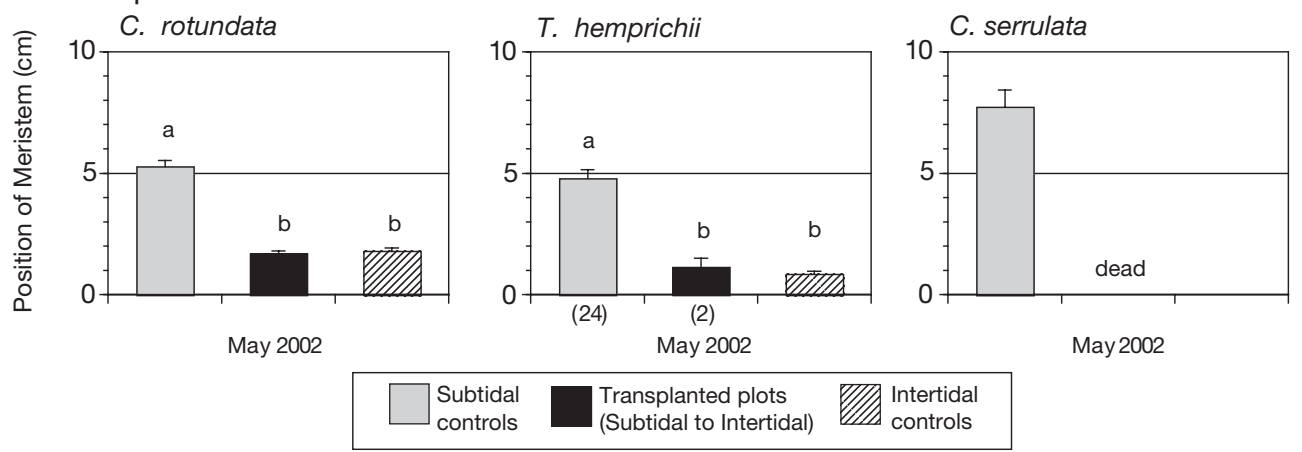

Fig. 8. Cymodocea rotundata, Thalassia hemprichii and C. serrulata. Temporal changes in position of meristem in transplantation experiments. Columns are the means of replicates, and error bars are the SE of the mean. Different letters denote pairs of treatments where significant among-treatment variation was detected by the post-hoc comparison. Sample size was 25 for each treatment except those shown in parentheses
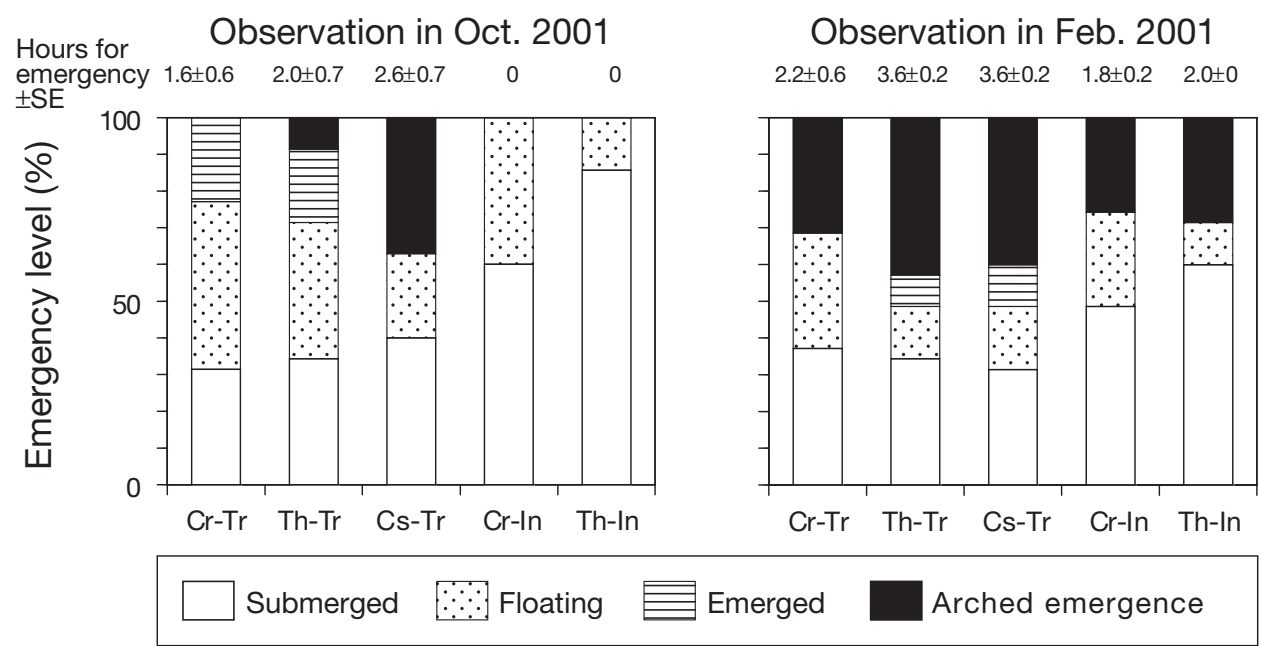

Fig. 9. Difference in emergence conditions among the transplantation treatments during daytime spring tide. Columns show the ratio of 4 emerging levels during $7 \mathrm{~h}$. Hours for emergence are calculated as emerged plus arched emergence. $\mathrm{Cr}-\mathrm{Tr}=\operatorname{trans}-$ planted plots of Cymodocea rotundata, Th-Tr = transplanted plots of Thalassia hemprichii, Cs-Tr $=$ transplanted plots of C. serrulata, $\mathrm{Cr}-\mathrm{In}=$ intertidal controls of $C$. rotundata, Th-In = intertidal controls of $T$. hemprichii 

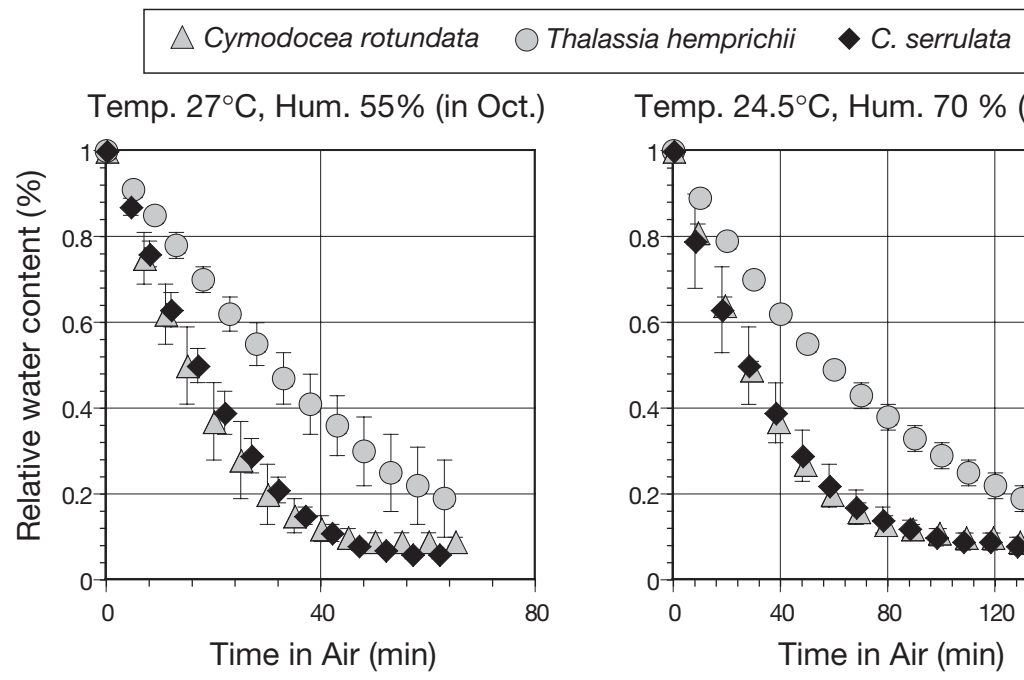

Temp. $24.5^{\circ} \mathrm{C}$, Hum. $70 \%$ (in Feb.)

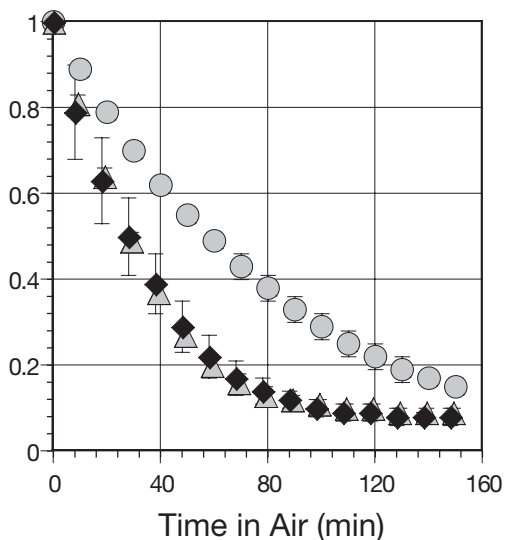

Fig. 10. Cymodocea rotundata, Thalassia hemprichii and C. serrulata. Change in water content of the leaves exposed to air in the desiccation experiment. Error bars are SD of the mean (6 replicates). Hum.: humidity

al. 1987), and in Tanzania (Björk et al. 1999), where $C$. rotundata and Thalassia hemprichii occur in shallower water than does C. serrulata.

This study also showed that the survival of seagrass changed seasonally with the seasonal changes in exposure to air. In July and September, when exposure was short, no decrease in shoot density was apparent. Conversely, in January, when exposure was long, the shoot density in the transplanted plots decreased significantly in all 3 species. Similar seasonal changes in seagrass abundance in relation to changes in the tide level have been reported for Enhalus acoroides and Thalassia hemprichii in Indonesia (Erftemeijer \& Herman 1994, Stapel et al. 1997), and Phyllospadix iwatensis in Japan (Yabe et al. 1995, 1996).

Comparing 8 tropical species of different sizes, Björk et al. (1999) showed that physiological tolerance of desiccation does not necessarily determine the upper limit of the distribution of seagrasses at intertidal sites. They found that Cymodocea rotundata and C. serrulata did not regain photosynthesis ability after losing $70 \%$ of their water, whereas Thalassia hemprichii showed a remarkable capacity to recover close to its original photosynthesis ability after losing $85 \%$ of its water (Björk et al. 1999). Our study also showed that $C$. rotundata and $C$. serrulata lose water much more quickly than does T. hemprichii (Fig. 10). These results suggest that it is highly likely that $C$. rotundata and $C$. serrulata leaves are more vulnerable to desiccation. However, this variation in physiological tolerance among the species does not coincide with the observed variation in the upper limits of distribution or the variation in survival measured in the transplantation experiment.
The observations of emergence conditions in the field showed that morphological variation among species is important in determining the upper limit of each species. When leaves are damaged, the efficiency of photosynthesis decreases. Moreover, if the meristem is lost, the shoots will die. Cymodocea rotundata has a short vertical rhizome (Fig. 4B) and a narrow strap-like sheath. This morphological characteristic allows the above sediment parts of this species to lie on the ground and remain in contact with the wet substrate, thus avoiding water loss when the seagrass bed is exposed. Thalassia hemprichii has a longer vertical rhizome and an inflexible sheath as compared to $C$. rotundata. Therefore, $T$. hemprichii is exposed to air for longer than is $C$. rotundata. However, this may be partly offset by the fact that the leaves of $T$. hemprichii have the greatest physiological tolerance to desiccation, as mentioned above. In addition, the large sheath of $T$. hemprichii may help to prevent water loss from the meristem.

Cymodocea serrulata is exposed to the air for longer than Thalassia hemprichii or C. rotundata because of its long vertical rhizome. In addition, the sheath of $C$. serrulata is narrower and lighter than those of the other 2 species and is kept away from the wet substrate by the long vertical rhizome; none of these characteristics are suitable for protecting the meristem from desiccation (Fig. 4C). Moreover, C. serrulata has leaves which have a low physiological tolerance to desiccation. Therefore, C. serrulata is the least tolerant of desiccation of the 3 species, and cannot survive in the intertidal area, as demonstrated by its extremely low survival in the transplantation experiment in February (Fig. 5C). The long vertical rhizome of C. serrulata is 
considered advantageous for obtaining light and for avoiding physical burial at deep subtidal sites (Vermaat et al. 1996, Duarte et al. 1997). However, this morphological character is a disadvantage to survive at the intertidal site.

Thalassia hemprichii and Cymodocea rotundata, which are both distributed in the intertidal and subtidal zones, showed great morphological within-species variation. In natural conditions, they have shorter vertical rhizomes and leaves in the intertidal zone than in the subtidal zone (Fig. 4A). Shorter vertical rhizomes reduce the probability of the meristem emerging, and shorter leaves decrease damage to photosynthetic organs. The reduced shoot size in the intertidal zone decreases the emergence probability, as shown in the observations of emergence condition (Fig. 9). Downsizing in the intertidal zone has also been observed in Halodule wrightii in the United States (Phillips 1967) and in Halophila ovalis, Halodule uninervis, and Zostera capricorni in Australia (Dawson \& Dennison 1996). Therefore, downsizing is considered one of the general responses of seagrasses to emergence stress.

In the transplantation experiment, the leaf sizes of Thalassia hemprichii and Cymodocea rotundata decreased drastically when transplanted from the subtidal zone to the intertidal zone (Fig. 7), which seems to be an adaptive trait for survival in an intertidal environment that is subjected to emergence stress. By contrast, we could not examine the degree of intraspecific variation in the leaf size plasticity of $C$. serrulata, because we lacked intertidal controls for this species. Nevertheless, a decrease in leaf size is not likely to increase survival in this species because the meristem is located above a long vertical rhizome. To increase survival during emergence, $C$. serrulata would need to produce new shoots with a shorter vertical rhizome.

In the long-term observations of the September plots (Fig. 8A), the meristems of transplanted Cymodocea serrulata were significantly closer to the substrate than were those in control plots, mostly owing to the production of new shoots with short vertical rhizomes. Shoot spacing along horizontal rhizomes was similar in all 3 species: 4.8, 6.9 and $5.3 \mathrm{~cm}$ for C. rotundata, Thalassia hemprichii, and C. serrulata, respectively, while the horizontal elongation rates were noticeably different: 34,21 and $78 \mathrm{~cm}$ apex ${ }^{-1} \mathrm{yr}^{-1}$, respectively (Vermaat et al. 1995). Hence, the productivity of new shoots is highest in C. serrulata. Moreover, elongation of the vertical rhizome is also highest in C. serrulata $\left(13 \mathrm{~cm}\right.$ shoot $\left.{ }^{-1} \mathrm{yr}^{-1}\right)$ as compared to $C$. rotundata $(1.5 \mathrm{~cm})$ and $T$. hemprichii $(3.0 \mathrm{~cm})$ (Vermaat et al. 1995), which prevents C. serrulata from surviving despite the high potential productivity of new shoots. Moreover, it takes longer to change morphological traits by producing new shoots than it does to change leaf size plastically, as observed in C. rotundata and $T$. hemprichii, and it is also more expensive. Hence, $C$. serrulata cannot adapt to the sudden change associated with emergence.

In conclusion, this study demonstrated that interspecies variation in tolerance to emergence stress is a significant factor influencing the upper limit of 3 midsized species in tropical seagrass beds. Inter-species variation in morphological traits, ability to change size plastically, and physiological tolerance of leaves to desiccation stress, including the water loss rate, are all involved in the inter-species variation in tolerance of emergence stress. Similar complex mechanisms may also explain the distribution of other seagrass species in subtropical areas. Further studies that also consider the morphological adaptation of seagrasses to emergence are important for elucidating the inter-species variation in distribution in mixed tropical seagrass meadows.

Acknowledgements. We thank M. Taira, H. Shimabukuro, Y. Umezawa, and N. Kouchi for assistance with the field research. The Fuyo Ocean Development Co., Ltd., and Marine Ecological Institute Co., Ltd., supported our field survey. Taisho Stainless Steel Co., Ltd., supplied the corer. Dr. T. Hayashibara and other staff at the Ishigaki Tropical Station of the Seikai National Fisheries Research Institute provided laboratory equipment. Dr. H. Kayanne, Dr. I. Koike, and Dr. T. Miyajima gave us invaluable support. We also thank Dr. K. L. Heck Jr. and 3 anonymous reviewers for their constructive comments. The Core Research for Environmental Science and Technology (CREST) program of the JAPAN Science and Technology Corporation supported this research.

\section{LITERATURE CITED}

Abal EG, Loneragan N, Bowen P, Perry CJ, Udy JW, Dennison WC (1994) Physiological and morphological responses of the seagrass Zostera capricorni Aschers to light-intensity. J Exp Mar Biol Ecol 178:113-129

Abe S, Kurashima A, Yokohama Y, Tanaka J (2001) The cellular ability of desiccation tolerance in Japanese intertidal seaweeds. Bot Mar 44:125-131

Bintz JC, Nixon SW (2001) Responses of eelgrass Zostera marina seedlings to reduced light. Mar Ecol Prog Ser 223: 133-141

Björk M, Uku J, Weil A, Beer S (1999) Photosynthetic tolerances to desiccation of tropical intertidal seagrasses. Mar Ecol Prog Ser 191:121-126

Davison IR, Pearson GA (1996) Stress tolerance in intertidal seaweeds. J Phycol 32:197-211

Dawson SP, Dennison WC (1996) Effects of ultraviolet and photosynthetically active radiation on five seagrass species. Mar Biol 125:629-638

Dennison WC, Alberte RS (1982) Photosynthetic responses of Zostera marina L. (eelgrass) to in situ manipulations of light intensity. Oecologia 55:137-144

De Troch M, Gurdebeke S, Fiers F, Vincx M (2001) Zonation and structuring factors of meiofauna communities in a tropical seagrass bed (Gazi Bay, Kenya). J Sea Res 45: $45-61$ 
Duarte CM, Terrados J, Agawin NSR, Fortes MD, Bach S, Kenworthy WJ (1997) Response of a mixed Philippine seagrass meadow to experimental burial. Mar Ecol Prog Ser 147:285-294

Erftemeijer PLA, Herman PMJ (1994) Seasonal changes in environmental variables, biomass, production and nutrient contents in two contrasting tropical intertidal seagrass beds in South Sulawesi, Indonesia. Oecologia 99:45-59

Huong TTL, Vermaat JE, Terrados J, Tien NV, Duarte CM, Borum J, Tri NH (2003) Seasonality and depth zonation of intertidal Halophila obalis and Zostera japonica in Ha Long Bay (northern Vietnam). Aquat Bot 75:147-157

Japan Meteorological Agency (2000) Tide tables for the year 2001. Japan Meteorological Agency, Tokyo (in Japanese)

Japan Meteorological Agency (2001) Tide tables for the year 2002. Japan Meteorological Agency, Tokyo (in Japanese)

Kayanne H, Suzuki A, Saito H (1995) Diurnal changes in the partial pressure of carbon dioxide in coral reef water. Science 269:214-216

Leuschner C, Landwehr S, Mehlig U (1998) Limitation of carbon assimilation of intertidal Zostera noltii and $Z$. marina by desiccation at low tide. Aquat Bot 62:171-176

Mukai H, Nojima S, Nishihira M (1987) Seagrass coverage and distribution in Loloata seagrass bed. In: A. Hattori (ed) Studies on dynamics of the biological community in tropical seagrass ecosystems in Papua New Guinea: the second report. Ocean Research Institute, University of Tokyo, Tokyo, p 18-27

Norton TA (1986) The zonation of seaweeds on rocky shores. In: Moore PG, Seed R (eds) The ecology of rocky coasts. Columbia University Press, New York, p 7-21

Olesen B, Enríquez S, Duarte CM, Sand-Jensen K (2002) Depth-acclimation of photosynthesis, morphology and demography of Posidonia oceanica and Cymodocea nodosa in the Spanish Mediterranean Sea. Mar Ecol Prog Ser 236:89-97

Phillips RC (1967) On species of seagrass, Halodule, in

Editorial responsibility: Kenneth Heck (Contributing

Editor), Dauphin Island, Alabama, USA
Florida. Bull Mar Sci 17:672-676

Seddon S, Cheshire AC (2001) Photosynthetic response of Amphibolis antarctica and Posidonia australis to temperature and desiccation using chlorophyll fluorescence. Mar Ecol Prog Ser 220:119-130

Stapel J, Manuntun R, Hemminga M A (1997) Biomass loss and nutrient redistribution in an Indonesian Thalassia hemprichii seagrass bed following seasonal low tide exposure during daylight. Mar Ecol Prog Ser 148:251-262

Tanaka Y (2004) Effect of physical environmental factors on community structure of tropical seagrass meadows. PhD thesis, University of Tokyo

Tomascik T, Mah AJ, Nontiji A, Moosa MK (1997) Seagrasses. In: Tomascik T, Mah AJ, Nontiji A, Moosa MK (eds) The ecology of the Indonesian seas, Part II. Periplus Editions, Singapore, p 829-906

van Tussenbroek BI (1996) Leaf dimensions of transplants of Thalassia testudinum in a Mexican Caribbean reef Lagoon. Aquat Bot 55:133-138

Vermaat JE, Agawin NSR, Duarte CM, Fortes MD, Marba N, Uri JS (1995) Meadow maintenance, growth and productivity of a mixed Philippine seagrass bed. Mar Ecol Prog Ser 124:215-225

Vermaat JE, Agawin NSR, Fortes MD, Uri JS, Duarte CM, Marba N, Enriquez S, Vierssen WV (1996) The capacity of seagrass to survive increased turbidity and siltation: the significance of growth form and light use. Ambio 25: 499-504

Yabe T, Ikushima I, Tsuchiya T (1995) Production and population ecology of Phyllospadix iwatensis Makino. I. Leaf growth and biomass in an intertidal zone. Ecol Res 10: 291-299

Yabe T, Ikushima I, Tsuchiya T (1996) Production and population ecology of Phyllospadix iwatensis Makino. II. Comparative studies on leaf characteristics, foliage structure and biomass change in an intertidal and subtidal zone. Ecol Res 11:291-297

Submitted: March 10, 2003; Accepted: July 28, 2004

Proofs received from author(s): December 2, 2004 